\title{
Linguistics and cognitive linguistics as tools of pedagogical discourse analysis
}

\author{
Yulia G. Kurovskaya ${ }^{1, *}$ \\ ${ }^{1}$ ISED RAE, Scientific Secretary, 105062, Moscow, Russia
}

\begin{abstract}
The article discusses the use of linguistics and cognitive linguistics as tools of pedagogical discourse analysis, thus establishing a new branch of pedagogy called pedagogical semiology that is concerned with students' acquisition of culture encoded in symbols and the way students' sign consciousness formed in the context of learning affects their world cognition and interpersonal communication. The article introduces a set of tools that would enable the teacher to organize the educational process in compliance with the rules of language as a sign system applied to the context of pedagogy and with the formation of younger generation's language picture of the world.
\end{abstract}

Personality formation is affected by a number of factors and conditions, including the educational environment and its tools. The right choice of pedagogical tools and the principles of the teaching process organization is directly related to the spiritual health of the nation and can therefore be viewed as an issue of state importance. The so-called 'matter' of the teaching process would be pedagogical discourse of the textbook. Textbook discourse and its features are of great pedagogical interest; nonetheless, they have been covered in few studies so far.

The notion of discourse that still has no unified and generally accepted scientific definition can be considered one of the key terms of pedagogy in general and textbook analysis in particular, for textbook discourse provides so-called "semantic accumulators" that accumulate, express, extend and construct discourse systems, as well as develop, re-formulate and confirm different educational theories. Although the notion of discourse was introduced into human sciences long ago, it has hardly been applied to pedagogical studies, presumably, because of the polysemy of the term, on the one hand, and the ambiguity of the notion, on the other hand.

Discourse is an object of interdisciplinary study. Discourse analysis can be traced back to two research schools, first, to the ethnolinguistic tradition that deals with spoken discourse of different languages (F. Boas' school of American ethnology), second, to the study of discourse topic and communicative organization (V. Mathesius' Prague Linguistic Circle).

Let us now address three main approaches to the understanding of discourse developed in the course of linguocultural, national, professional, and individual research. These approaches are linguistic, structuralist, and communicative.
The linguistic approach is generally believed to be based on the linguistic definition of the term introduced by American linguist Zellig Harris in his paper "Discourse Analysis" in 1952. Regardless of the modern variability of linguistic definitions of discourse, they all still share the desire to precise and develop the traditional understanding of such notions as speech, text and dialogue. Moreover, there have been attempts to add a third element, discourse, to the dichotomy of speech and language (suggested by Saussure and now accepted as a classic model). On the one hand, the third element would be 'more spoken' (informal, individual, concrete) that speech, on the other hand, 'more linguistic' (formal, social, abstract) than language. Therefore, discourse as "speech immersed in life" (a metaphor suggested by N.D Arutyunova) is integrated and actualized in a communicative situation, whereas discourse as a language structure consists of information flows actualized in the course of a dialogical (linguistic) interaction. Pedagogical "speech immersed in life" that embodies the dynamics of teaching and students' language, discursive picture of the world formation is the textbook regarded as a didactic tool of a special type. This interpretation of the "discourse" term is mostly presented by the Anglo-Saxon tradition.

The structuralist approach to discourse that has recently become popular in mass media was introduced in French structuralism and post-structuralism, first of all including M. Foucault's studies, and further developed in the papers of such scholars as A. Greimas, J. Derrida, J. Kristeva, and M. Pêcheux. Thus, upon analyzing the features of the French school of discourse analysis, which was founded in the 1960s and combined linguistics, L. Althusser's Marxian philosophy, and psychoanalysis, P. Sériot differentiated

\footnotetext{
* Corresponding author: kurovskaya@mail.ru
} 
between the following definitions of the term discourse:

1. An equivalent to the term speech as Saussure defined it, i.e. any particular utterance. 2. A unit of speech with the size above an utterance; the object of text grammar studying sequences of separate utterances. 3. In terms of the theory of utterance or pragmatics, discourse is considered as the effect it produces on the receiver and its "utterance" situation (which is composed of the speech subject, the addressee, the time and place of the utterance). 4. In case of the narrowing of its third meaning, discourse denotes a conversation regarded as the main type of communication. 5. É. Benveniste defines discourse as speech that belongs to the speaker, whereas narration develops without the subject's explicit interference. 6 . Sometimes language and speech ( $f r$. langue / discours) are opposed to each other as, on the one hand, a system of slightly differentiated virtual meanings and, on the other hand, as the diversity on the surface level and the diversity in the usage of linguistic units. Thus, we distinguish between the study of the unit in language and speech. 7. The term discourse is often employed to denote the system of limitations that are induced by a particular social or ideological stance and influence the infinite number of utterances. Thus, any reference to "feminist discourse" or "administration discourse" would not be considered in isolation from other texts but rather in the context of their typical language features. 8. Traditionally, DA (discourse analysis author's note) defines the object of its study by distinguishing between enouncement and discourse, where enouncement is a sequence of expressions placed between two semantic gaps, two communicative pauses, and discourse is an enouncement regarded in the terms of the discursive mechanism it is governed by. That means that as long as the text is viewed as a language construct, it is called enouncement, whereas the linguistic study of text factors would define it as discourse. [1]

In text grammar, didactic discourse presupposes an impact on the reader and a conversation aimed at information acquisition, it favors only one (privileged) language by discarding other (non-status) ones, and provides constraints, directions, and guidance. The textbook produces didactic discourse and, as a result, forms the 'grammar' of education. The latter identifies the textbook as a means to introduce discourses from various historical periods and lay the foundation for the worldview and system (hierarchy) of values. [2]

The notion of discourse as it is understood according to the communicative approach can be traced back to German philosopher and sociologist J. Habermas and is defined as a special and ideal kind of communication, which occurs in utmost isolation from social reality, traditions, authorities, communicative routine and so on, and centers on the discussion and justification of the participants' opinions and actions.

The variety of ways to understand the notion of discourse noted above might require some ordering. In this paper, discourse is viewed as a mediator between the language of pedagogy and pedagogical speech and, as a result, combines the features of both. The "language" features include the rules of language use and productive pedagogical language patterns that ensure successful student-teacher communication and mutual understanding. The "speech" features are determined by the actualization of meaning of particular lexemes in the course of communicative interaction and by the individual character of their edition manifestation.

In this paper the discourse in textbook is regarded as the way the textbook verbally presents the world depending on the communicative situation (it might be a perpetual or temporal - past, present or future perspective). Thus, discourse acquires features determined by a particular communicative situation and, due to it, surpasses an abstract notion. It is determined by the teacher's and students' semiotic (i.e. linguistic and behavioral) strategies aimed at communicative interaction, where communication is always defined as the exchange of signs and meanings, which either correlate to the topic of conversation or accompany it. Textbook pedagogical discourse could be thus described as a special institutional (formally pedagogical) way of world description and world cognition introduced in the educational environment, where the latter is construed around specific communicative aims and social roles of home, group or school teaching.

In order to determine pedagogical discourse features, one should take into account the aim, participants, chronotopos and type / genre of the source text used by the teacher, of the verbalized piece of discourse. [3] If discourse is a text embedded in a situation, "speech immersed in life", pedagogical discourse is the speech of the educational process and interaction within it. Pedagogical discourse may be identified as a way to verbally present the world in the course of learning and world cognition and as a speech activity aimed at new society members' socialization. It is given in basic education discourse, professional discourse, complementary education discourse, and so on. Employed in teaching and communication, pedagogical discourse is an open non-linear system of semiotic (through textbooks and other semiotic entities) teacher - student interaction governed by either a pedagogical situation or a pedagogical aim.

The objectives, methods and means of pedagogical discourse, regardless of the institution (educational institution) belongs to, correspond to the formation, development and shaping of the student's personality in the course of teaching. It is typical of discourse to assign roles to the participants of communication and distinguish between the teacher and the student. Moreover, discourse identifies the objectives set by the tradition or situation; that would be the development of one's main competences in the professional context, the personality's successful socialization in the context of the society, and individual formation of psychophysiological, social and personal characteristics in the context of personal development. [4]

Textbook pedagogical discourse serves to provide semiotic, informational, cultural, and anthropological 
foundations; it simultaneously represents the results of teaching and the process of their achieving. It can be itself defined as a foundation or "competence". The quality of this foundation secures the quality and reliability of the whole educational system.

The effectiveness of teaching is determined by external (social and educational environment) as well as corresponding internal factors (students' and teachers' personality qualities and motives). The external factors of textbook pedagogical discourse would include a language system, a typographic culture, participants' personality qualities and the setting of communication. The understanding of pedagogical discourse as a complex system of interaction involving participants different in their role and status suggests the introduction and application of an integrated complex set of tools of its analysis.

What should be the tools that enable one to comprehend textbook pedagogical discourse, which is a tool itself, be like? In order to answer this question, we would first like to discuss the nature of discourse. As discourse is the way to present the world verbally, its nature is linguistic (symbolic) and prescribes contextual use of language. In this case, the first level of the cognition of the essence and an effective tool of its analysis should be linguistics, which studies language as a system. Linguists' indirect study of language is opposed to the traditional "direct" perception of specific language units, for instance, written and spoken texts including those that imitate native speakers' speech acts or texts of "educated people" (the restricted number of written texts in extinct languages that are no longer used as the basic means of communication). [5]

Language is characterized by its sign-symbolic nature, so linguistics can be regarded as a branch of semiotics, the study of signs. Upon developing the course of general linguistics F.de Saussure, for instance, combined semiotics (which he called semiology) and linguistics. As pedagogical discourse may be considered as the object of semiology and as linguistics represents an integral part of semiology, the analysis of pedagogical discourse would require the use of the tool of linguistics.

Pedagogical discourse sets boundaries, within which the participants of the educational process speak, on the one hand, about the world with its peculiarities and features, and, on the other hand, about values and ideas that are integrated in the world and at the same time encompass it. Communication is presented in different types of discourse: mathematics, physics, chemistry, and everyday discourse. Meanwhile, linguistics sets the limitations of language (symbolic) use of phonetic, morphological, lexical and semantic, stylistic, phraseological, syntactic phenomena so that they corresponded to the aims of pedagogical interaction. If we accept the significant part the signs (and symbols) play in one's life in general and communicative interaction in particular, it is possible to address the notion of sign, which is traditionally related to F. de Saussure in linguistics, and apply this notion to the textbook.
It is worth mentioning that according to $\mathrm{F}$. de Saussure, the sign is defined by the dichotomy of the signifier and the signified with the linguistic sign described as a two-sided psychological entity, which is composed of the signified (notion) and the signifier (a form of the sign, an acoustic image in Saussure's theory and a graphic, sometimes also visual, image in the modern interpretation), which are closely bonded and form a unified whole just like two sides of the same sheet of paper do. [6] The Saussurean tradition describes language as a system of significations, where the meaning is the relation of the signified to the signifier, and the value is the sign as it is determined by its position and relations to other language signs. If we returned to the comparison of the sign to the sheet of paper, the meaning would be the relationship between the two sides of the sheet, whereas the value would be the relation between several sheets.

The structural linguistic analysis of pedagogical discourse that develops Saussure's ideas presupposes that discourse should be divided into segments and analyzed according to its inner textual (semiotic) characteristics that include its semantic and structural connectedness, discreteness, coherence, means of topic transition, modality of short and long texts (semiotic entities) and sets of texts, and discursive polyphony as the type of communication (the exchange of signs) on several levels of the text at once (a macrosign). The linguo-stylistic analysis of textbook discourse allows one to identify and choose the register of communication (the exchange of signs) and the genre preferences of the discourse type (semiotic flows) and to determine the communicative functions according to its units (corresponds to the functional style). The socio-linguistic analysis of textbook pedagogical discourse centers on the general social context of communication and the participants of communication as the representatives of a particular social group.

Now that we have elaborated on the three methods of discourse analysis, we would like to mention the next level of pedagogical discourse, cognitive linguistics. In the terms of cognitive linguistics, language is a tool of cognition and world structuralization. As a tool of pedagogical discourse cognition, cognitive linguistics answers how effective the technique of speaking about the world (pedagogical discourse) suggested by the author, publication or textbook; comments on the way and level of the student's language (sign-symbolic) comprehension; and determines how by mastering the curriculum the student forms a concept, i.e. a fragment of his picture of the world, which conventionalizes the language society's world perception with the help of language and later forms the worldview of its member through learning.

One of the keys terms of textbook pedagogical discourse analysis may therefore be the cognitive notion concept. The term concept first appeared in the Russian linguistic studies at the end of the 20th century and the beginning of the 21 st century [7]. In this paper, we would not discuss the debatable definition of the term, as the notion is controversial and relies on non- 
linguistic entities. Here it is regarded from the pedagogical point of view and may be defined as a unit of meaning, a fragment of the student's picture of the world formed by teaching. The concept is verbalized (implicitly or explicitly) in didactic texts. It is a cognitive structure, which is built in one's mind in the process of learning; it originates in the textbook and is instantiated by language means (symbols). The textbook, thus, performs the role of a "membrane" or mediator conveying meaning, inducing a corresponding "echo" from the student and ensuring his ability to reproduce the concept later.

From the perspective of cognitive linguistics, pedagogical discourse is considered as a semiotic entity, which is studied through concepts, frames, scenarios, mental schemes, cognitive types, in other words, through different mental models of displaced interaction between the student and the teacher with the textbook as a mediator. These mental models include the values and worldview of the teacher, the author of the textbook, and, as a result, the student. In addition to it, cognitive linguistics as a tool of pedagogical discourse analysis determines communicative features of the ethnic group and the culturally coded models of etiquette and language behavior, identifies and presents the cultural peculiarities of the language society in the form of concepts, as well as establishes the norms and patterns of conventional texts of the linguocultural society.

To conclude, it is worth mentioning that pedagogical discourse analysis conducted with the help of linguistics, semiology, and cognitive linguistics is a new approach to pedagogy, which has rather recently been assigned to a separate branch of pedagogy called pedagogical semiology (introduced by Mikhail A. Lukatsky, Dr.Sc. (Education), Professor, Corresponding Member of the Russian Academy of Education, Head of the Laboratory of Philosophy of Education and Theoretical Pedagogy of the Federal State Budget Scientific Institution "Institute for Strategy of Education Development of the Russian Academy of Education" [16]). Pedagogical semiology denotes a branch of pedagogy, which "studies pedagogical discourse patterning, including the introduction of new pedagogical terms and exclusion of outdated ones, identifies and defines the concepts of the pedagogical environment that are new to the scientific community" [17]. As a result, pedagogical semiology may symbolize the further development of the pedagogical science, in general, and provide new opportunities to the study of pedagogy, in particular.

\section{References}

1. Kvadratura smysla: Frantsuzskaya shkola analiza diskursa. Obshch. red. i vstup. st. P. Serio; predisl. Yu.S. Stepanova (Progress, Moscow, 1999) [In Rus]

2. K. Khaintse, Ot sistematizatsii znanii $k$ pedagogizatsii. Diskursivno-analiticheskie podkhody i innovatsionno-teoreticheskie perspektivy. "Nachalo ucheniya detyam»: rol' knigi dlya nachal'nogo obucheniya $v$ istorii obrazovaniya i kul'tury (Kanon+, Moscow, 2014) [In Rus]

3. V.I. Karasik, O tipakh diskursa. Yazykovaya lichnost': institutsional'nyi i personal'nyi diskurs. Sb. nauch. tr. (Peremena, Volgograd, 2000) [In Rus]

4. V.I. Karasik, Yazykovoi krug: lichnost', kontsepty, diskurs (Gnozis, Moscow, 2004) [In Rus]

5. F. de Sossyur, Kurs obshchei lingvistiki (Editorial URSS, Moscow, 2004) [In Rus]

6. Ibid.

7. N.D. Arutyunova, Yazyk i mir cheloveka (Yazyki Russkoi Kul'tury, Moscow, 1999) [In Rus]

8. D.S. Likhachev, Izvestiya AN SSSR. Seriya literatury i yazyka 1, 3-9 (1993) [In Rus]

9. Kratkii slovar' kognitivnykh terminov, Pod obshchei redaktsiei E.S. Kubryakovoi (Izdatel'stvo MGU, Moscow, 1996) [In Rus]

10. Yu.S. Stepanov, Slovar' russkoi kul'tury. Opyt issledovaniya (Shkola "Yazyki russkoi kul'tury», Moscow, 1997) [In Rus]

11. V.I. Karasik, Yazykovoi krug: lichnost', kontsepty, diskurs (Gnozis, Moscow, 2004) [In Rus]

12. V.P. Neroznak, Ot kontsepta $k$ slovu: $k$ probleme filologicheskogo kontseptualizma. Voprosy filologii $i$ metodiki prepodavaniya inostrannykh yazykov (Omsk, 1998) [In Rus]

13. N.N. Boldyrev, Kognitivnaya semantika: Kurs lektsii po angliiskoi filologii (TGU, Tambov, 2001) [In Rus]

14. Z.D. Popova, I.A. Sternin, Ocherki po kognitivnoi lingvistike ("Istoki", Voronezh, 2001) [In Rus]

15. Z.D. Popova, I.A. Sternin, Ponyatie «kontsept»v lingvisticheskikh issledovaniyakh (Voronezh, 1999) [In Rus]

16. M.A. Lukatskii, Otechestvennaya i zarubezhnaya pedagogika, 5(14), 62-76 (2013) [In Rus]

17. M.A. Lukatskii, Tsennosti i smysly, 6(40), 56-64 (2015) [In Rus] 